\title{
ELABORATION OF ANALYSIS METHODOLOGY MEANT \\ TO ENHANCE THE EFFICIENCY OF BUSINESS ENTITY'S INTERNATIONAL TRADE
}

\section{O. Martyanova ${ }^{1}$}

DOI: http://doi.org/10.15350/L_26/8/12

\section{Abstract}

In the context of current economic uncertainty the business entities are looking for ways to enhance their activity on the international level. Franchising is one of the possible options to consider. In order to provide a rationale for the managerial decision on the use of a foreign contractor's franchise one needs a set of tools enabling to evaluate the project proposal as well as select the optimal one from a variety of available offers. The paper provides theoretical and methodological grounds for the contemporary system of franchise agreements analysis which facilitate decision making on the manufacturing technology purchase based on financial and economic evaluation of contractual conditions as well as the analysis of financial consequences of implementing an international trade project based on probabilistic Markov modelling.

Keywords: efficiency, international trade, franchise agreement, net present value, sensitivity analysis, risk assessment, final probabilities, modelling, normalizing condition.

Intensification of politicization in international economic relations is typical for contemporary foreign trade. It is expressed in politically motivated sanctions representing barriers for the projects that are economically mutually-beneficial. This is bound to result in uncertainty and risks of the long term stagnation on the global market, which hinders the players involved from fulfilment their full potential. Taking into consideration high vulnerability of international trade, any decision made by the market participants involved in international trade must be well-grounded and maximum prudent.

The complexity and multicriteriality of the objectives pursued by the member-entities of the international trade in the framework of the new economic model require accurate consideration of the multidimensional character of processes going on in the international trade, change of theoretical and methodological approaches to establishing the efficiency analysis system applicable to the international trade, development of tool ware complied with the contemporary conditions of international trade for evaluation and interpretation of information. The set of tools is meant to facilitate efficient decision making, because the systems ignoring the currently existing conditions on the market are eventually brought to bankruptcy.

High volatility and instability of international trade relations, numerous restrictions imposed on international trade determined the necessity for exportimport operations evaluation, development of the efficiency analysis system for

10lga Martyanova, Candidate of Economic Sciences, doctoral candidate The Orel State University of Economics and Trade, Russia. 
the entity international trade based on contemporary methods of information and analytic research in order to provide rationale for the elaboration of methodologically new international trade. The analysis system applicable to international trade is meant to offer a complex assessment of resources, sources, mechanisms, and outcomes of the business entity's development in a particular sector of economy. Based on the results of this analysis it is deemed necessary to develop and implement the mechanism of value management in international trade transactions.

The tool ware available for international trading partners is labour consuming and inaccurate, therefore it is not possible to choose the best from a variety of options in the most optimal way. A complex analysis of effective economic attractiveness, prognostication and decision making optimisation implemented based on economic and mathematical modelling should be accepted as the basis for efficient decision making. All abovementioned proves the relevance and demand for the research aimed at the development and elaboration of methodological and practical grounds for establishing the system of efficiency analysis in corporate international trade as the rationale for the business unit development.

Lack of investments, remoteness of Russia from the global market, technological inferiority, low performance and poor management quality constitute the problems which force the business entities look for their own sources to keep up with the world economic growth rate, which eventually enables the companies to preserve their share in the global market. Companies involved in brewing business face huge difficulties in this respect. It is evidenced from the global production analysis for the period 2013-2016 that the niche for the brewery business is quite limited (Fig. 1). Nevertheless, we believe that export of goods should be viewed as the driving force for the development of Russian companies working in this business sector.

Nowadays the national producers may enter the global market only based on their international integrity business reputation of a competitive good supplier. For a variety of reasons the number of such suppliers is rather low. A franchise system may be a success story in this respect. Franchising represents diversified business with the global brands. This issue has become rather urgent for the brewing companies particularly beginning from 2016, when large-scale acquisitions in the sector eventually resulted in a new market structure both in Europe and other countries.

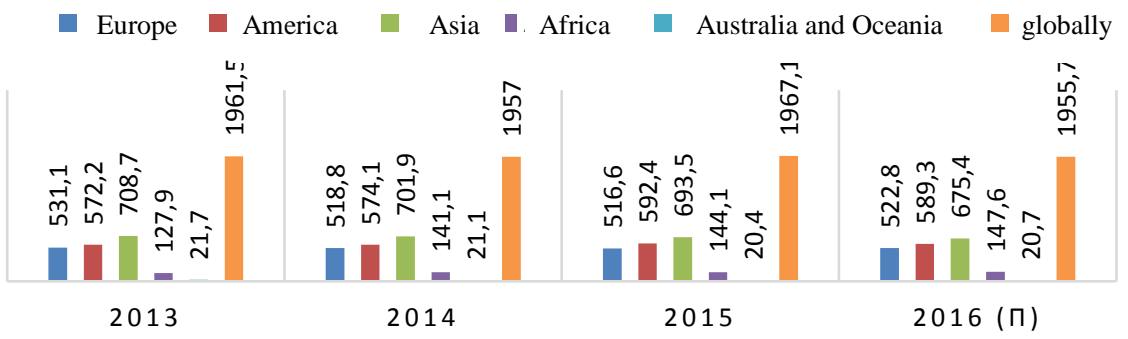

Source: E-malt.RU

Fig. 1. Global brewing production in 2013-2016 
Thus, a Japanese company Asahi purchased the Grolsch and Peroni brands which originally belonged to SABMiller, and added such central European brands as Pilsner Urquell, Topvar, Dreher, Ursus, Lech, and Tyskie. China Resources purchased a share of SABMiller's which amounted to $49 \%$ of their joint brewery company C.R. (Snow) and became its sole proprietor. In the African market the $\mathrm{AB}$ InBev company implements the strategy of significant expansion of its presence, which nowadays amounts to $43 \%$ of the continental market share. This is mainly due to the fact that the volume of beer sales in Africa boosted from $61 \mathrm{mln}$ gallon in 2000 to $142 \mathrm{mln}$ gallon in 2015. By 2025 the anticipated amount is 175 mln gallon, which may force the company to initiate cooperation with Castel Group in the region. In the USA Molson Coors acquired MillerCoors, however preserving both names, which divided the brewery market on the American continent in the following way: AB InBev - 44\%, MillerCoors - 25\%, Constellation $7 \%$, Heineken USA - 4\%, Pabst - 3\%, other brewing companies - $17 \%$. The Russian market, being one of the most complicated brewery markets in the world also tried to keep pace with the occurring transformations. AB InBev and Efes which have a number of brewing plants in Russia are planning to merge 11 of them into a new brewing company capable to take $27 \%$ of the market share, second after Baltika brand which has $34 \%$ of the national brewery market. It is worth mentioning that $\mathrm{AB}$ InBev increased its share on the global brewery market to $27 \%$ after acquiring its immediate competitor SABMiller. The second largest global brewing company is Heineken (9\%), followed by Carlsberg (6\%), Molson Coors and Chinese Snow, Tsingtao и Yanjing [1].

In the context of brewery business extension the franchise system is one of the models enabling a company to optimize its expenses when entering the global market in terms of advertising, brand mark development, equipment purchase, if its cost is included into a franchise package, and finally, the product price due to wholesale discounts offered to international suppliers. Franchising in international trade has numerous disadvantages as well. These include format restrictions, location and general look of the business establishment, range of goods that are bound by the franchise agreement along with the lack of flexibility in the business management.

Despite the fact that franchising is one of the most effective ways for the development of a certain business area, including international trade, the business enterprises should all the same dispose their own tool ware enabling them to make a decision on whether to pay for long-term leasing of the brand or the production technology taking into consideration both financial and non-financial factors. We argue, that it is worthwhile assessing long-term franchise offers followed by strategic decisions based on the net present value (NPV), because it suggests a simple rule for decision making and takes into consideration the regulations stipulated in the theory of "time value for money", which ensures the business entity's profit is complied with its maximum value in the current business environment. This approach has certain restrictions, i.e. lack of information on the return rate of initial cash outlay, prognostic value of cash flow, absence of criteria for discount rate assessment, which altogether may represent certain challenges when implementing this approach. 
The practical implementation of the decision making method is provided below. The approach considers a net present value when making a decision on the franchise agreement concerning a production technology of a number of upmarket beer brands and their consequent sales under the export contracts. The data of a production company provided in the management statements are used as the information bases. In compliance with the franchise agreement a franchisee pays annual royalty in the amount of 920 thousand euro, and incurs expenses on brewing equipment maintenance. The amount of royalty is fixed and is not subject to change even under inflation. Royalty payments are due by the end of the calendar year. For more details on a franchise agreement refer to Table 1.

Table 2

Conditions of a franchise agreement

\begin{tabular}{|l|r|}
\hline \multicolumn{1}{|c|}{ Parameter } & Amount \\
\hline Turnover, thousand litres/year & 690,00 \\
\hline Increase in sales per year, \%/year & 2,7 \\
\hline Indicators of the 1st year & 9,50 \\
\hline Selling price, euro/litre & 5,61 \\
\hline Variable costs, euro/litre & 345,00 \\
\hline Fixed costs, thousand euro & \\
\hline Investment in equipment & 920,00 \\
\hline When making a franchise agreement, thousand euro & 460,00 \\
\hline At the beginning of the 5th year, thousand euro & 115,00 \\
\hline Residual value, thousand euro & 69,00 \\
\hline Amount of operating capital, thousand euro & 12,5 \\
\hline Depreciation rate, \% & 20,00 \\
\hline Taxable rate, \% & \\
\hline Share of the tax charged paid & 80,00 \\
\hline In a tax liability year, \% & 20,00 \\
\hline In a year following the tax liability year, \% & 5,4 \\
\hline Inflation, \%/год & 15,8 \\
\hline Cost of capital, \%/year & \\
\hline
\end{tabular}

Before making a decision on whether to buy a franchise for upmarket beer production technology, it is necessary to assess cash inflows as well as tax payments (Table 2). 
Table 2

Assessment of cash flows in franchising

\begin{tabular}{|c|c|c|c|c|c|c|c|c|}
\hline $\begin{array}{l}\text { Term } \\
\text { Indicator }\end{array}$ & $\begin{array}{c}1 \\
\text { year }\end{array}$ & $\begin{array}{c}2 \\
\text { year }\end{array}$ & $\begin{array}{c}3 \\
\text { year }\end{array}$ & $\begin{array}{c}4 \\
\text { year }\end{array}$ & $\begin{array}{c}5 \\
\text { year }\end{array}$ & $\begin{array}{c}6 \\
\text { year }\end{array}$ & $\begin{array}{c}7 \\
\text { year }\end{array}$ & $\begin{array}{c}8 \\
\text { year }\end{array}$ \\
\hline $\begin{array}{l}\text { Volume of sales, } \\
\text { thousand litres }\end{array}$ & 690,00 & 708,63 & 727,76 & 747,41 & 767,59 & 788,32 & 809,60 & - \\
\hline $\begin{array}{l}\text { Marginal profit } \\
\text { per litre, euro/li- } \\
\text { tre }\end{array}$ & 3,89 & 4,10 & 4,32 & 4,55 & 4,79 & 5,05 & 5,32 & - \\
\hline $\begin{array}{l}\text { Net profit, } \\
\text { thousand euro }\end{array}$ & 2684,10 & 2905,38 & 3143,94 & 3400,73 & 3676,77 & 3981,00 & 4307,08 & - \\
\hline $\begin{array}{l}\text { Royalty, thousand } \\
\text { euro/year }\end{array}$ & 920,00 & 920,00 & 920,00 & 920,00 & 920,00 & 920,00 & 920,00 & - \\
\hline $\begin{array}{l}\text { Fixed costs, } \\
\text { thousand euro }\end{array}$ & 345,00 & 363,56 & 383,12 & 403,73 & 425,45 & 448,34 & 472,46 & - \\
\hline $\begin{array}{l}\text { Net cash inflow, } \\
\text { thousand euro }\end{array}$ & 1419,10 & 1621,82 & 1840,82 & 2076,99 & 2331,32 & 2612,66 & 2914,62 & - \\
\hline $\begin{array}{l}\text { Residual value of } \\
\text { assets, thousand } \\
\text { euro }\end{array}$ & 920,00 & 805,46 & 705,18 & 1077,39 & 943,25 & 825,82 & 723,01 & - \\
\hline $\begin{array}{l}\text { Depreciation, } \\
\text { thousand euro }\end{array}$ & 114,54 & 100,28 & 87,79 & 134,14 & 117,43 & 102,81 & 608,01 & - \\
\hline $\begin{array}{l}\text { Taxable income, } \\
\text { thousand euro }\end{array}$ & 1304,56 & 1521,54 & 1753,03 & 1942,85 & 2213,89 & 2509,85 & 2306,61 & - \\
\hline $\begin{array}{l}\text { Profit tax, } \\
\text { thousand euro }\end{array}$ & 260,91 & 304,31 & 350,61 & 388,57 & 442,78 & 501,97 & 461,32 & - \\
\hline \multicolumn{9}{|l|}{ Tax payment: } \\
\hline $\begin{array}{l}\text { In the year of tax } \\
\text { liability emer- } \\
\text { gence, thousand } \\
\text { euro }\end{array}$ & 208,73 & 243,45 & 280,49 & 310,86 & 354,22 & 401,58 & 369,06 & - \\
\hline $\begin{array}{l}\text { In the year, fol- } \\
\text { lowing the year of } \\
\text { tax liability emer- } \\
\text { gence, thousand } \\
\text { euro }\end{array}$ & - & 52,18 & 60,86 & 70,12 & 77,71 & 88,56 & 100,39 & 92,26 \\
\hline $\begin{array}{l}\text { Tax cash flow, } \\
\text { thousand euro }\end{array}$ & 208,73 & 295,63 & 341,35 & 380,98 & 431,94 & 490,13 & 469,45 & 92,26 \\
\hline
\end{tabular}


In order to provide rationale for the financial consequences resulting from making a franchise agreement we attempt to calculate the net present value of this long-term project. The details can be viewed from Table 3.

Table 3

Efficiency evaluation of a franchise agreement

\begin{tabular}{|l|c|c|c|c|c|c|c|c|c|}
\hline \multicolumn{1}{|c|}{$\begin{array}{c}\text { Term } \\
\text { Indicator }\end{array}$} & $\begin{array}{c}0 \\
\text { year }\end{array}$ & $\begin{array}{c}1 \\
\text { year }\end{array}$ & $\begin{array}{c}2 \\
\text { year }\end{array}$ & $\begin{array}{c}3 \\
\text { year }\end{array}$ & $\begin{array}{c}4 \\
\text { year }\end{array}$ & $\begin{array}{c}5 \\
\text { year }\end{array}$ & $\begin{array}{c}6 \\
\text { year }\end{array}$ & $\begin{array}{c}7 \\
\text { year }\end{array}$ & $\begin{array}{c}8 \\
\text { year }\end{array}$ \\
\hline $\begin{array}{l}\text { Investment, } \\
\text { thousand euro }\end{array}$ & $(920,00)$ & - & - & - & $(460,00)$ & - & - & 115,00 & - \\
\hline $\begin{array}{l}\text { Operating } \\
\text { capital, } \\
\text { thousand euro }\end{array}$ & $(69,00)$ & - & - & - & - & - & - & 69,00 & - \\
\hline $\begin{array}{l}\text { Net cash flow, } \\
\text { thousand euro }\end{array}$ & - & 1419,10 & 1621,82 & 1840,82 & 2076,99 & 2331,32 & 2612,66 & 2914,62 & - \\
\hline $\begin{array}{l}\text { Tax payment, } \\
\text { thousand euro }\end{array}$ & - & $(208,73)$ & $(295,63)$ & $(341,35)$ & $(380,98)$ & $(431,94)$ & $(490,13)$ & $(469,45)$ & $(92,26)$ \\
\hline $\begin{array}{l}\text { Net cash flow } \\
\text { ffter tax pay- } \\
\text { ment, thou- } \\
\text { sand euro }\end{array}$ & $(989,00)$ & 1210,37 & 1326,19 & 1499,47 & 1236,02 & 1899,38 & 2122,53 & 2629,17 & $(92,26)$ \\
\hline $\begin{array}{l}\text { Discount } \\
\text { factor }\end{array}$ & 1,000 & 0,862 & 0,743 & 0,641 & 0,552 & 0,476 & 0,410 & 0,354 & 0,305 \\
\hline $\begin{array}{l}\text { Present value } \\
\text { (PV), thou- } \\
\text { sand euro }\end{array}$ & $(989,00)$ & 1043,34 & 985,36 & 961,16 & 682,28 & 904,10 & 870,24 & 930,73 & $(28,14)$ \\
\hline $\begin{array}{l}\text { Net present } \\
\text { value (NPV), } \\
\text { thousand euro }\end{array}$ & & & & & & & & & \\
\hline
\end{tabular}

Based on the calculations above it is deemed possible to make a decision on the benefit of the franchise agreement for the purchase of upmarket beer production technology, because the net present value is positive. Upon assessing the project proposal using a net present value method we may conclude that this franchise agreement is bound to be financially efficient in the long run.

Franchise agreement is always a risk-bearing commercial venture, i.e. international trade risk. In order to manage it effectively it is necessary to carry out a sensitivity analysis of the decision made upon the franchise agreement to the change of upmarket beer sales produced in accordance with the technology purchased from a foreign partner. The results of the calculation are provided in Table 4. 
Table 4

\begin{tabular}{|c|c|c|c|c|c|c|c|c|}
\hline $\begin{array}{l}\text { Term } \\
\text { Indicator }\end{array}$ & $\begin{array}{c}1 \\
\text { year }\end{array}$ & $\begin{array}{c}2 \\
\text { year }\end{array}$ & $\begin{array}{c}3 \\
\text { year }\end{array}$ & $\begin{array}{c}4 \\
\text { year }\end{array}$ & $\begin{array}{c}5 \\
\text { year }\end{array}$ & $\begin{array}{c}6 \\
\text { year }\end{array}$ & $\begin{array}{c}7 \\
\text { year }\end{array}$ & $\begin{array}{c}8 \\
\text { year }\end{array}$ \\
\hline $\begin{array}{l}\text { Marginal profit, } \\
\text { thousand euro }\end{array}$ & 2684,10 & 2905,38 & 3143,94 & 3400,73 & 3676,77 & 3981,00 & 4307,08 & - \\
\hline $\begin{array}{l}\text { Profit tax, } \\
\text { thousand euro }\end{array}$ & $(536,82)$ & $(581,08)$ & $(628,79)$ & $(680,15)$ & $(735,35)$ & $(796,20)$ & $(861,42)$ & - \\
\hline Tax payment: & & & & & & & & \\
\hline $\begin{array}{l}\text { In the year of tax } \\
\text { liability, thousand } \\
\text { euro }\end{array}$ & $(429,46)$ & $(464,86)$ & $(503,03)$ & $(544,12)$ & $(588,28)$ & $(636,96)$ & $(689,13)$ & - \\
\hline $\begin{array}{l}\text { In the year, fol- } \\
\text { lowing the year of } \\
\text { tax liability, thou- } \\
\text { sand euro }\end{array}$ & & $(107,36)$ & $(116,22)$ & $(125,76)$ & $(136,03)$ & $(147,07)$ & $(159,24)$ & $(172,28)$ \\
\hline $\begin{array}{l}\text { Net cash flow af- } \\
\text { ter tax payment, } \\
\text { thousand euro }\end{array}$ & 2254,64 & 2333,16 & 2524,69 & 2730,85 & 2952,46 & 3196,97 & 3458,71 & $(172,28)$ \\
\hline Discount factor & 0,862 & 0,743 & 0,641 & 0,552 & 0,476 & 0,410 & 0,354 & 0,305 \\
\hline $\begin{array}{l}\text { Present value } \\
(\mathrm{PV}) \text {, thousand } \\
\text { euro }\end{array}$ & 1943,50 & 1733,54 & 1618,33 & 1507,43 & 1405,37 & 1310,76 & 1224,38 & $(52,55)$ \\
\hline $\begin{array}{l}\text { Net present value } \\
\text { of the marginal } \\
\text { profit (NPV), thou- } \\
\text { sand euro }\end{array}$ & \multicolumn{8}{|c|}{10690,76} \\
\hline $\begin{array}{l}\text { Investment sensi- } \\
\text { tivity related to } \\
\text { sales, \% }\end{array}$ & \multicolumn{8}{|c|}{$5360,07: 10690,76=50,14$} \\
\hline
\end{tabular}


According to our reckoning, the sensitivity analysis represents a modelling process which makes it possible to define the impact of the changes in the values of significant variables onto the prognosticated result. These variables include discount rate inflow and outflow of cash. This data facilitate optimum decision making. The obtained results are indicative of the sensitivity of a franchise agreement to the change in sales. The international trade project undergoing analysis will no longer work if the volume of sales decreases by $50.14 \%$. For the decision maker such a risk may be inappropriate. However, in order to make a final decision which is bound to guarantee the efficiency of international trade of a business entity due to a franchise agreement it is necessary to assess the sensitivity of the project to the changes of other variables.

Under uncertainty the business entity should be aware of the cost of franchise agreements currently existing on the market as well as the options of its change in midterm which will enable the economic entity to make a decision enhancing the efficiency of international trade, provided that this decision is not time-bound.

In order to obtain accurate results when prognosticating on the franchise market in the target sector it makes sense to model it using Markov processes. The procedure of making an optimal decision based on the analysis of predicted estimate using Markov processes tool ware is indicated below. In the course of market research of franchise ventures proposed by international brewing companies the marketing department of our business entity defined that the royalty of a franchise agreement on the upmarket beer production technology may vary within the range from 840 thousand euro to 1,160 thousand euro per year.

In this regard a decision maker should evaluate the rationale for making a franchise agreement on brewing technology with the annual royalty amounting to 920 thousand euro.

In order to solve the task, let us denote the brewing production technology franchise as $S$. For the purpose of our research we will assess those conditions of the system which are characterised by the amount of a franchise agreement royalty within the following range:

$s_{1}$ - from 840 thousand euro to 930 thousand euro;

$s_{2}$ - from 930 thousand euro to 1000 thousand euro;

$s_{3}$ - from 1000 thousand euro to 1100 thousand euro;

$s_{4}$ - from 1100 thousand euro to 1160 thousand euro.

The market value of the franchise agreement in the target sector substantially depends on its current cost at this date. The supply price on the market may change at any moment as a result of random market effects. The transfer to system $S$ from one condition into another occurs with probability density fixed in time, with the values indicated in matrix (1).

$$
\delta=\left(\begin{array}{llll}
0 & 7 & 0 & 2 \\
1 & 0 & 5 & 4 \\
3 & 6 & 0 & 1 \\
2 & 0 & 8 & 0
\end{array}\right) .
$$


On the assumption of the primary data the system $S$ features a discrete homogeneous Markov process in continuous time. Therefore, the flow of events causing the systems' transfer from one condition to another is simple. The marked state graph is provided in Fig. 2.

The analysis of the graph shows that in a finite number of steps the system $S$ may transfer in any other state, i.e. such system is ergodic. It is evidenced from [2,p. 115] that if the number of states of system $S$ is finite, the system $S$ is ergodic and all the flows of events causing the systems' transfer from one state to another are simple, then there are final probabilities of states $\left(p_{i}\right)$, defined as follows:

$$
p_{i}=\lim _{t \rightarrow+\infty} p_{i}(t), i=1, \ldots, n
$$

where $p_{i}(t)$ - state probability $s_{i}$ of system $S$ at time $t$.

In order to define final probabilities is it appropriate to use differential equation system developed by Kolmogorov, which is presented as follows:

$$
\frac{d p_{i}(t)}{d t}=-\left(\sum_{j=1}^{n} \lambda_{i j}\right) p_{i}(t)+\sum_{j=1}^{n} \lambda_{i j} p_{j}(t), \quad i=1, \ldots, n ; \quad t \geq 0 .
$$

If we shift to the limit in equation (3) for $t \rightarrow+\infty$, then it is converted into a system of homogenous algebraic linear equations for $n$ unknown $p_{-} \mathrm{i}, \mathrm{i}=1, \ldots, \mathrm{n}$, expressed as follows [3, p. 72]

$$
-\left(\sum_{j=1}^{n} \lambda_{i j}\right) p_{i}+\sum_{j=1}^{n} \lambda_{i j} p_{j}=0, \quad i=1, \ldots, n
$$

Since the probability of the continuous random value p_i (t) for $t \rightarrow+\infty$ tends to a fixed value p_i, while the derivative of a fixed value equals a zero.

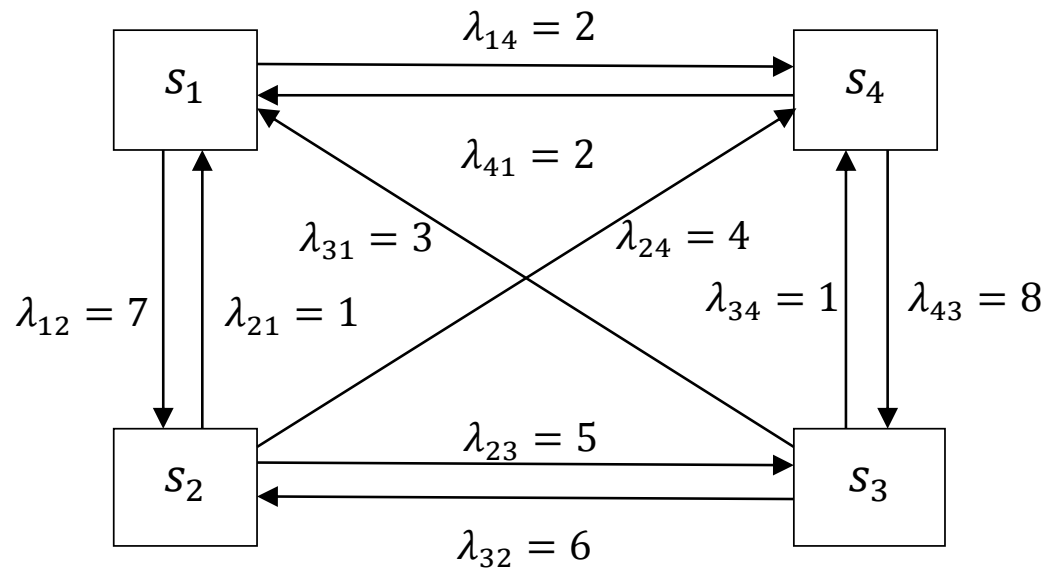

Figure 2. State graph of the system under study

Based on the abovementioned, we'll from the equations set

$$
\left\{\begin{array}{c}
-9 p_{1}+p_{2}+3 p_{3}+2 p_{4}=0 \\
7 p_{1}-10 p_{2}+6 p_{3}=0 \\
5 p_{2}-10 p_{3}+8 p_{4}=0 \\
2 p_{1}+4 p_{2}+p_{3}-10 p_{4}=0
\end{array}\right.
$$


Upon transformation of the equation set (5) we will get

$$
\begin{aligned}
& \left\{\begin{array}{c}
-9 p_{1}+p_{2}+3 p_{3}+2 p_{4}=0 ; \\
p_{2}=0,7 p_{1}+0,6 p_{3} ; \\
p_{4}=0,875 p_{3}-0,437 p_{1} ; \quad \text { or } \\
p_{1}=0,583 p_{3}
\end{array}\right. \\
& \left\{\begin{aligned}
-9 p_{1} & +p_{2}+3 p_{3}+2 p_{4}=0 ; \\
p_{2} & =1,008 p_{3} \\
p_{4} & =0,62 p_{3} ; \\
p_{1} & =0,583 p_{3} .
\end{aligned}\right.
\end{aligned}
$$

Consequently, the general solution for the system (5), depending on one arbitrary parameter $p_{-} 3 \in[0,1]$, is vector

$$
\left(p_{1}=0,583 p_{3} ; \quad p_{2}=1,008 p_{3} ; \quad p_{3} ; \quad p_{4}=0,62 p_{3}\right) \text {. }
$$

If we change the first equation with a normalized condition, we get a system, which makes it possible to find the solution meeting the required conditions out of a number set:

where

$$
\left\{\begin{array}{l}
p_{1}+p_{2}+p_{3}+p_{4}=0 \\
p_{2}=1,008 p_{3} \\
p_{4}=0,62 p_{3} \\
p_{1}=0,583 p_{3} .
\end{array}\right.
$$

$$
\left\{\begin{array}{l}
p_{1}=0,181 \\
p_{2}=0,313 \\
p_{3}=0,311 \\
p_{4}=0,193
\end{array}\right.
$$

Thus, the estimated market value of the franchise agreement on the purchase of the upmarket beer production technology is as follows: in the mediumterm perspective the most probable franchise value will be within the range between 930 thousand euro and $1 \mathrm{mln}$ euro. Therefore, the company may enter into a franchise agreement of premium beer manufacturing technology purchase with the annual royalty in the amount of 920 thousand euro, incurring the minimum risk.

Systematizing the carried out calculation allows drawing the following conclusions:

1. The analysis of franchise agreement should be carried out using the method of net present value, which enables the business entity to explain the consequences of participating in the international trade projects in the mediumterm perspective as well as provide rationale for the managerial decision, taking into consideration both financial and non-financial factors. This does not mean that franchise agreement should not be evaluated using other methods, facilitating decision making in the medium-term and long-term perspective and should allow choosing the option enhancing the efficiency of the business entity's international trade.

2. Sensitivity analysis for risk evaluation of the franchise agreement will enable to reveal the parameters most sensitive for the net present value.

3 . The analysis carried out proved that economic and mathematical modelling based on Markov processes makes it possible first of all, to evaluate the 
validity of the project proposals, and secondly, select the most optimal franchise project for a variety of available options, which is bound to ensure the competitive advantage of the company in international trade.

\section{References}

[1] 2016 became year of the largest absorption in the history of brewing [Electronic resource]. URL: http://e-malt.ru/News.asp?Command=ArticleShow\&ArticleID=4078

[2] Labsker L.G. Probabilistic modeling in financial and economic area [Text]: education guidance / L.G. Labsker. The second edition M.: INFRA-M, 2014. 172 pp.

[3] Martyanova O.V. Model of an import substitution efficiency evaluation in the conditions of uncertainty on the basis of final probabilities of system [Text] / O.V. Martyanova // Domestic science during an era of changes: postulates of the past and theory of modern times: The collection of scientific articles following the results of the XIV International scientific and practical conference Yekaterinburg, on October 0910, 2015 Yekaterinburg: National association of scientists. Monthly scientific magazine. Part 2. 2015. № 9(14). P. 68-74. 